\title{
Validation of Natural Cosmetic Resources Containing EtOH Extracts of Chrysanthemum indicum and Cymbopogon cirtratus by the Simultaneous Analysis of Their Marker Compounds Using High Performance Liquid Chromatography-Diode Array Detector
}

Ju Eun Kim, Jae Yoon Leem*

Department of Pharmacy, Woosuk University, Wanju-gun, Jeolabuk-do, Korea

\author{
*Corresponding author: Jae Yoon Leem, \\ Department of Pharmacy, Woosuk \\ University, 443, Samnye-ro, Samnye-eup, \\ Wanju-gun, Jeolabuk-do 55338, Korea \\ Tel.: +82632901575 \\ Fax: +82632901561 \\ Email: jyleem@woosuk.ac.kr
}

Received October 20, 2020

Revised December 03, 2020

Accepted December 08, 2020

Published December 30, 2020

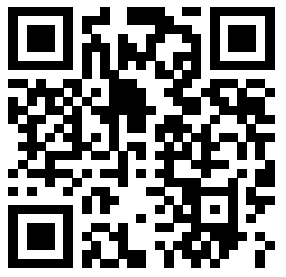

\begin{abstract}
Purpose: Recently, the demand for natural extracts and naturally derived ingredients from core raw materials has increased in the cosmetic industry, but their manufacturing and quality control standards are not sufficiently established. This study aims to standardize the compositions of marker compounds from natural cosmetics using ethanol extracts of Chrysanthemum indicum (Cl) and Cymbopogon cirtratus (CC). The method is then validated. Methods: In liquid chromatography (LC)/mass spectrometry, astragalin and $p$-coumaric acid were determined as the marker compounds for quantitative analysis. The performances (linearity, accuracy, and precision) of these two marker components were simultaneously analyzed in a mixture of both natural products using high-performance liquid chromatography with a diode array detector (HPLC-DAD). Results: The marker compounds of $\mathrm{Cl}$ and $\mathrm{CC}$ in the extracts were determined as astragalin and $p$-coumaric acid, respectively. The detected marker compounds from the $\mathrm{Cl}$ and $\mathrm{CC}$ showed significant linearity $\left(\mathrm{R}^{2} \geq 0.9999\right)$. The astragalin and $p$-coumaric acid markers achieved limits of detection of 1.20 and $0.07 \mathrm{ng} / \mathrm{mL}$, respectively, and limits of quantification of 3.59 and $0.22 \mathrm{ng} / \mathrm{mL}$, respectively. The marker concentrations were $0.24 \mu \mathrm{g} / \mathrm{mL}$ in Cl and $1.55 \mu \mathrm{g} / \mathrm{mL}$ in CC. Conclusion: This study suggests that the developed method may be an important basic data for the manufacturing and quality control of natural cosmetic.
\end{abstract}

Keywords: Validation, Simultaneous analysis, Anti-oxidant, Chrysanthemum indicum, Cymbopogon cirtratus

\section{Introduction}

화장품 구매에 있어 성분이 주요 결정 요인으로 부상하는 가운데, 소비자들의 화학물질 공포증(chemical phobia)이 심해지며 천연 원료 에 대한 수요가 증가하고 있다. 또한, 소비자들은 천연제품을 선호하 면서도 여러 가지 효능을 갖춘 기능성을 원하기 때문에, 이를 뒷받침 할 기능성 화장품 소재 개발이 요구된다. 최근, 국내에서도 지역 특화 기능성 소재 개발이 시도되고 있다. 그 중 한 예로, 말 사업 특구로 지 정된 제주의 말 부산물을 활용하여 피부 건강 증진 효과가 있는 펩타 이드를 분리하는 원천 기술을 개발하여, 화장품 업체에 기술을 이전한
사례가 있다. 이러한 기능성 천연 추출물 또는 천연 유래 화합물로 환 경/인간 친화적인 화장품 천연 소재를 개발해 적용하는 기술이 필요 하다.

천연 화장품은 천연물을 사용하여 부작용이 적고, 작용이 일반적으 로 온화, 지속적이며 생분해성이 높아 환경친화적인 장점이 있으나, 유효성분 또는 약리작용이 밝혀지지 않거나 유효성분의 함량이 일정 하지 않아 원료물질의 유효성분의 함량을 정확하게 특정할 수 없으면 제품의 기능성에 대한 신뢰도를 얻기가 어려우며, 이를 위한 소재에 관한 개선 연구가 필요한 실정이다(Bae, 2017; Ahn, 2017).

감국(甘菊)은 국화과의 여러해살이풀로 황국(黄菊)이라고도 하며 
생약명으로는 야국화(野菊花), 의화(義花), 야황국(野黃菊)이라 한다 (Kim, 1998). 동의보감에서 감국은 풍으로 어지럽고 머리가 아픈 것 을 치료하며, 예막을 없애고 눈을 밝게 하며 눈의 피를 길러주고 내장 을 치료하며 바람이 불면 눈물이 나는 것을 멎게 한다고 기록되어 있 다(Heo, 2008). 한방에서 열감기, 폐렴, 기관지염, 두통, 위염, 장기, 종기 등의 치료에 처방한다. 보고된 활성으로는 노화와 주름 생성 경 감(Kim, 2016) 항암 활성, 산화스트레스 저해, 항산화 활성, 결핵균 및 바이러스 등에 대한 항박테리아 효과 등이 보고되어 있다(Kim et al., 2005; Park et al., 2011; Woo et al., 2010). 감국의 성분으로는 eugenol, isoeugenol, cynaroside, apigetrin 등이 보고되어 있다(Hyun et al., 2019).

레몬그라스(Cymbopogon cirtratus)는 향아(香芽)라는 이름이 있지 만, 통상적으로는 레몬그라스로 불린다. 향료를 채취하기 위하여 열 대지방에서 재배하며 레몬 향이 나는 허브의 일종으로 외떡잎식물 벼 목 화본과의 여러해살이풀이다. 레몬그라스는 잎과 뿌리를 증류하여 얻은 향유(香油)에는 시트랄(citral)이 들어있어 비누와 약품 등의 향료 로 사용한다. 수프, 소스 등과 같은 요리에도 사용되며, 살균작용이 있 어 복통, 설사, 두통, 발열의 치료에 사용된다. 보고 된 활성으로는 피 부보습 및 피부장벽개선(So et al., 2019), 항산화, 지방세포 분화 억제 효과, 항암, 항염증 활성 등이 보고 되어있으며(Bhattacharya, 1998; Francisco, 2014), 성분으로는 $\alpha$-pinene, camphene, limonene, myrcene, citral 등이 보고 되어있다(Jo et al., 2019).

본 연구 그룹은 기존 선행연구에서 기능성 천연 화장품 소재의 개 발 및 원료 표준화를 위해 남원에서 자생하는 허브 및 외래종으로 재 배하고 있는 천연물 원료의 10 종에 대한 항산화 활성 평가 및 그 중 산 구절초, 자소엽, 찔레의 동시 분석을 통한 유효성분을 정량 평가하였 다(Ham et al., 2018). 본 연구에서는 총 플라보노이드와 폴리페놀함 량이 높은 소재인 감국 (Chrysanthemum indicum, CI)과 레몬그라스 (Cymbopogon cirtratus, $\mathrm{CC}$ )를 선정하여 $\mathrm{DPPH}$ 라디칼소거능 평가 및 $\mathrm{HPLC}-\mathrm{DAD}$ 를 이용한 지표 성분의 동시 분석법을 개발하였다. 또한, 이의 타당성을 검증하기 위해 직선성, 범위, 특이성, 정확성, 정밀성, 검출한계 등의 분석법 밸리데이션을 수행하였다.

본 연구에서 수립한 분석법 밸리데이션을 활용하여 감국, 레몬그라스 를 함유하는 천연화장품의 개발단계부터 제품생산 단계에 이르기까지 원료소재의 품질관리와 제조관리에 응용할 수 있을 것으로 사료된다.

\section{Methods}

\section{1. 실험 재료}

감국 $(\mathrm{CI})$ 과 레몬그라스 $(\mathrm{CC})$ 의 지상부를 전라북도 남원시에서 5 월에 수확한 생물로 구입하였다. $40^{\circ} \mathrm{C}$ 에서 $72 \mathrm{~h}$ 건조(LD9013; L'EQUIP Co., Korea)한 후, 분쇄기(HMF-3600TG; Hanil Electric, Korea) 를 이용하여 분쇄하여 $100 \mathrm{~g}$ 에 $50 \%$ 에탄올 $2 \mathrm{~L}$ 를 넣어 $80^{\circ} \mathrm{C}$ 에서 4 $\mathrm{h}$ 동안 추출하였다. 그 후, 추출물은 2 회 여과하여 감압농축기 $(\mathrm{R}-$ 100 ; $\mathrm{BUCHI}$, Switzerland)를 이용하여 $50^{\circ} \mathrm{C}$ 에서 농축하고 동결건조 (MCFD8508; IlshinBiobase Co., Korea)하여 시료로 사용하였다. 추 출 수율은 약 $17 \%$ 이었다.

\section{2. 시약}

표준품 astragaline, $p$-coumaric acid는 HPLC grade (순도 98\% 이상)로 Chengdu Biopurify Phytochemicals (Chengdu, China)에서 구입하여 사용하였다. Acetonitrile, methanol, water는 J.T Banker (Phillipburh, USA)에서, formic acid는 Fluka (Wunstorfer strasse, Germany)에서 구입하였으며, 분석에 사용한 모든 시약은 HPLC grade를 사용하였다.

\section{3. $\mathrm{DPPH}$ 라디칼 소거 활성}

2,2-diphenyl-1-picryldrazyl (DPPH) 라디칼 소거 활성은 Blois법 (Blois, 1958)을 변형하여 측정하였다. 일정 농도로 희석한 시료 2.5 $\mu \mathrm{L}$ 에 $10 \mu \mathrm{M}$ DPPH (Sigma Aldrich, USA) 용액 247.5 $\mu \mathrm{L}$ 를 더한 뒤, 차광하여 실온에서 $20 \mathrm{~min}$ 반응시킨 후 ELISA Reader (Bio-Rad Heciles, USA)를 사용하여 $517 \mathrm{~nm}$ 에서 흡광도를 측정하였다. 각 시 료는 3 회 반복 실험을 실시한 뒤, 각 시료의 활성이 $50 \%$ 감소할 때 나 타나는 시료의 농도 $\left(\mathrm{RC}_{50}\right)$ 를 구하였다. 양성대조군은 L-ascorbic acid (Amresco, USA)를 사용하였다.

\section{4. 분석 시료의 전처리}

$\mathrm{HPLC}$ 분석을 위한 시료는 $100 \mathrm{mg}$ 을 취해 $10 \mathrm{~min}, 50 \%$ 에탄올 1 $\mathrm{mL}$ 로 초음파 추출한 뒤, $0.2 \mu \mathrm{m}$ membrane filter (PALL Co., USA) 로 여과하여 사용하였다. 지표 성분의 표준품은 각각의 표준품을 10 $\mathrm{mg}$ 을 $100 \mu \mathrm{L}$ 의 $50 \%$ 에탄올에 녹인 뒤, $0.2 \mu \mathrm{m}$ membrane filter (PALL Co.)로 여과하여 사용하였다. 시료의 희석은 $10 \%$ 에탄올로 희 석한 뒤 분석하였다.

\section{HPLC 분석 조건}

지표 성분의 함량을 분석하기 위하여 Hitachi Chromaster HPLC CM5000 system (Hithachi, Japan)을 사용하였으며, 검출기는 Diode assay detector (DAD)를 사용하였다. 칼럼은 YMC-Pack ODS-AM, $\mathrm{C} 18250 \times 4.6 \mathrm{~mm}$ I.D. (YMC, Japan)를 사용하였다. 칼럼 온도는 $40^{\circ} \mathrm{C}$ 로 유지하였고, 유속은 $1.0 \mathrm{~mL} / \mathrm{min}$ 조건으로 분석했다. 이동 상은 $0.1 \%$ formic acid가 함유된 DW (A)와 $0.1 \%$ formic acid가 함유 된 acetonitrile (B)을 사용하였으며 이동상의 기울기는 0-2 $\mathrm{min},(\mathrm{A})$ : 100\% 2-50 min (A): 60\%, 50-55 min, (A): 0\%, 55-60 min, (A): 0\%, 60-65 min, (A): 100\%, 65-70 min, (A): 100\%로 분석했다. 검 출 파장은 $237 \mathrm{~nm}$ 와 $248 \mathrm{~nm}$ 에서 검출하였다. HPLC 데이터 분석은 Agilent Open Lab software를 사용하였다(Lee, 2018). 


\section{6. 분석법 밸리데이션}

확립된 동시 분석법에 대하여 식약처에서 고시한 의약품 밸리데이 션 가이드라인에 따라 직선성(linearity), 범위(range), 검출한계(LOD), 정량한계(LOQ), 정확성(accuracy), 정밀성(precision)등을 판단하여 분 석방법을 검증하였다(NIFDS, 2015; KFDA, 2008; Yong, 2019).

\section{7. 직선성 및 범위}

지표 성분들을 네 가지 농도 $(0.1,1,10,50 \mu \mathrm{g} / \mathrm{mL})$ 로 희석하여 3 회 분석 후 얻은 결과를 가지고 표준 검량선(calibration curve) 및 회기방 정식(regression equation)을 작성하여 직선성을 평가했다.

\section{8. 특이성}

감국, 레몬그라스 $50 \%$ 에탄올추출물의 혼합물과 각각의 지표 성분 들을 혼합한 표준품 혼합액을 제조한 뒤, 분석하여 얻은 크로마토그램 을 시각적으로 평가하고, 해당 지표 성분의 UV 스펙트럼을 시료와 표 준품의 혼합액의 크로마토그램에서 추출하여 비교하는 것으로 평가하 였다.

\section{9. 정확성 및 정밀성}

정확성과 정밀성 모두 지표 성분의 피크의 적분 값을 비교하는 방법 으로 측정하였다. 정확성은 세 가지 농도의 표준품을 시료에 첨가하여 분석한 후 회수율을 측정하는 방법으로 평가하였고, 정밀성은 균일한 검체로부터 여러 번 채취하여 얻은 시료를 정해진 조건에 따라 측정 하였을 때 각각의 측정값들 사이의 근접성으로 상대표준편차(relative standard deviation, \%RSD)로 판단하였다. 즉, 일내(intra-day)와 일 간(inter-day) 시험을 통하여 실시하였다. 각각의 실험은 3가지 농도 의 혼합표준용액을 3 회 반복 실험을 통하여 얻는 결과의 상대표준편차 를 구하여 평가하였다.

\section{0. 검출한계 및 정량한계}

검출한계 및 정량한계는 작성한 검량선을 토대로 아래의 식을 이용 하여 계산하였다.

검출한계 $=3.3 \times[$ 반응의표준편차 $(\sigma) /$ 검량선의기울기 $(\delta)]$

정량한계 $=10 \times[$ 반응의표준편차 $(\sigma) /$ 검량선의기울기 $(\delta)$ ]
표준품 분석을 통해 작성한 검량선을 토대로 직선의 식에 특정 표준 품의 면적값을 대입하고, 비례식을 이용하여 계산하였다.

\section{Results and Discussion}

\section{DPPH 라디칼 소거능 활성}

감국과 레몬그라스의 $\mathrm{DPPH}$ 라디칼을 $50 \%$ 소거하는데 필요한 시 료의 농도 $\left(\mathrm{RC}_{50}\right)$ 를 Table 1 에 나타내었다. 실험결과, 감국 $50 \%$ 에 탄올추출물에서 $48.32 \pm 1.07 \mu \mathrm{g} / \mathrm{mL}$, 레몬그라스 $50 \% 50 \%$ 에탄 올추출물에서 $48.51 \pm 1.44 \mu \mathrm{g} / \mathrm{mL}$ 로 나타났으며, 두 추출물을 혼 합했을 때는 $37.96 \pm 0.31 \mu \mathrm{g} / \mathrm{mL}$ 로 나타났다. 양성대조군으로 사 용한 L-ascorbic acid $(52.10 \pm 0.49 \mu \mathrm{g} / \mathrm{mL})$ 보다 단일 추출물일 때 약 1.1 배, 혼합 추출물일 때 1.4 배 더 강한 소거 활성을 나타내었 다. 감국과 레몬그라스를 단독으로 사용하는 것 보다는 혼합물로 사 용하는 것이 항산화 활성을 더욱 강화한다는 것을 알 수 있다. Ham et al. (2018) 이 산구절초, 자소엽, 찔레의 조합물에 관해 보고한 바 와 같이, 산구절초나 찔레 단독으로 사용하는 것보다 자소엽과의 혼 합물로 사용하는 것이 항산화 활성을 증강시킨다. 물론 자소엽의 $\mathrm{DPPH}$ 소거능이 매우 우수하여 상대적으로 활성이 약한 산구절초와 찔레의 활성을 증강시킨 점이 예상된다. 그러나 본 연구에서는 감국 과 레몬그라스의 DPPH 소거능이 비슷하지만 동량 혼합에 의해 그 활성이 약 $28 \%$ 증가되었으며 이는 두 소재의 항산화 활성을 나타내 는 유효성분이 상호작용하여 상승효과를 나타낸 것으로 추론된다. 화장품 조성물로서 항산화 효능을 최대화하기 위해서 단일 추출물 보다 복합추출물을 사용하는 것이 효과적일 것으로 사료 되며, 감국 과 레몬그라스 외에도 선행 연구로 보고 한 소재들을 적절한 조합의 추출물로 사용할 때 그 효능이 더욱 극대화될 것이며, 각 소재의 항 산화 활성과 조합 비율에 관한 연구가 더 필요하다고 사료 된다.

\section{2. 지표 성분의 정성, 정량 분석}

문헌 조사 및 LC/MS 분석을 통하여(데이터 미 제시) 지표 성분들 로 예상되는 물질들을 몇 가지 선택하여, HPLC 분석을 통하여 각 지표 성분들의 표준 검량선을 구하였다. Table 2 에 나타낸 바와 같 이, 검량선의 상관계수는 0.9999 이상이었으며 직선성을 나타내었 다. 동시에 감국과 레몬그라스 내의 지표 성분들의 함량을 구하기

\section{1.함량 평가}

\section{$\mathrm{RC}_{50}$ Value $(\mu \mathrm{g} / \mathrm{mL})$ \\ $48.32 \pm 1.07$ \\ $48.51 \pm 1.44$ \\ $37.96 \pm 0.31$ \\ $52.10 \pm 0.49$}

DPPH, 1,1-diphenyl-2-picrylhydrazyl; Cl, Chrysanthemum indicum L.; CC, Cymbopogon citratus; Mix, mixture of $\mathrm{Cl}$ and $\mathrm{CC}$; $\mathrm{RC}_{50}$ value, concentration at which DPPH is reduced by $50 \%$ in a 20 min reduction. 

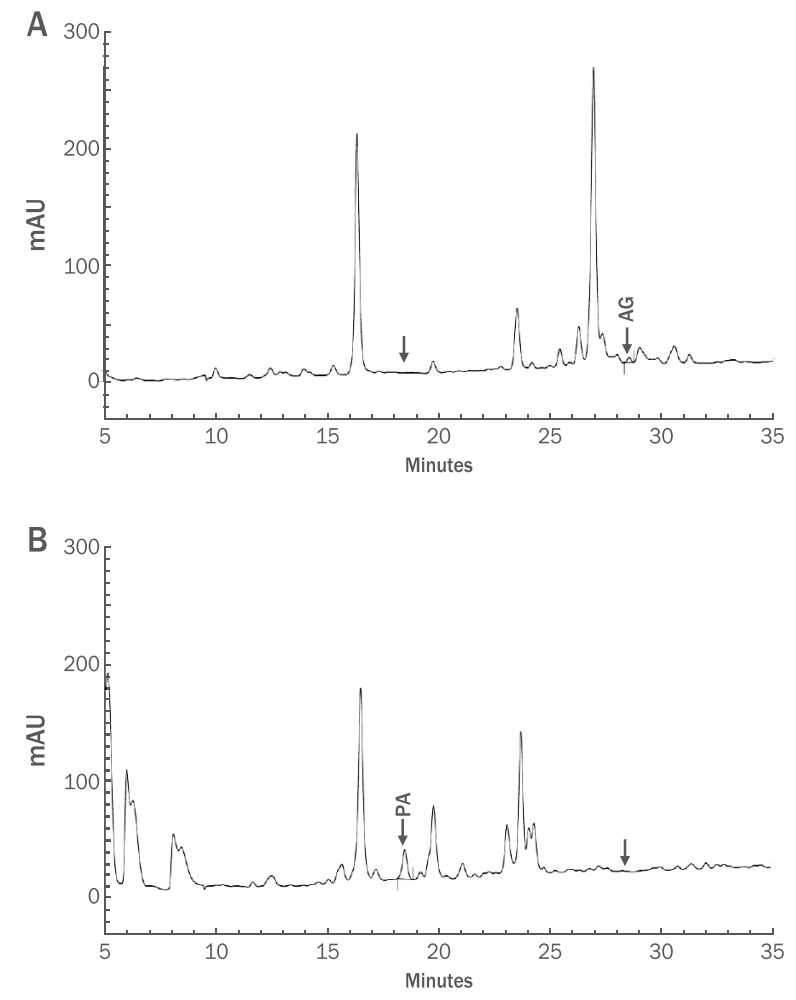

A

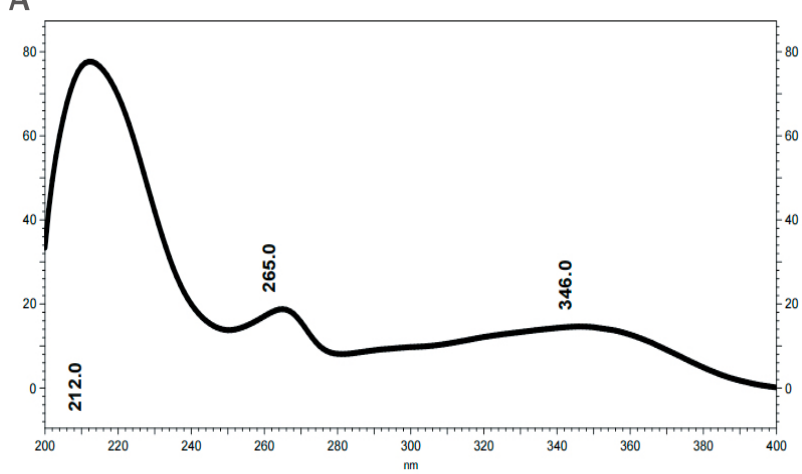

C

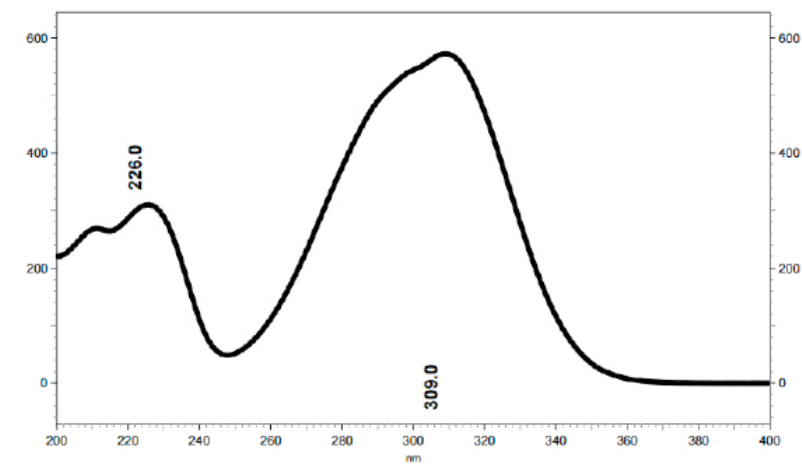

C<smiles></smiles>

$A G$<smiles>O=C(O)/C=C/c1ccc(O)cc1</smiles>

PA

Figure 1. HPLC profile of $50 \%$ EtOH extract (Cl or CC), and the str uctures of marker compounds.

(A), HPLC profile of marker compound from the $50 \%$ EtOH extract of $\mathrm{Cl}$ at $237 \mathrm{~nm}$; (B), HPLC profile of marker compound from the $50 \% \mathrm{EtOH}$ extract of $\mathrm{CC}$ at $237 \mathrm{~nm}$. In the HPLC profile of $\mathrm{Cl}, \mathrm{A}$ $\mathrm{G}$ (28.5 min) was detected but PA was not detected (18.5 min). Conversely, in the HPLC profile of CC, PA (18.5 min) was detected , but AG was not detected (28.5 min). To analyze the $\mathrm{Cl}$ and CC ex tracts simultaneously, AG and PA were selected as the indicator co mponents of $\mathrm{Cl}$ and $\mathrm{CC}$, respectively (despite being detected in $\mathrm{s}$ mall amounts). (C), Structures of the marker compounds AG and PA. Cl, Chrysanthemum indicum L.; CC, Cymbopogon citratus; AG, astragalin, PA, $p$-coumaric acid.

B

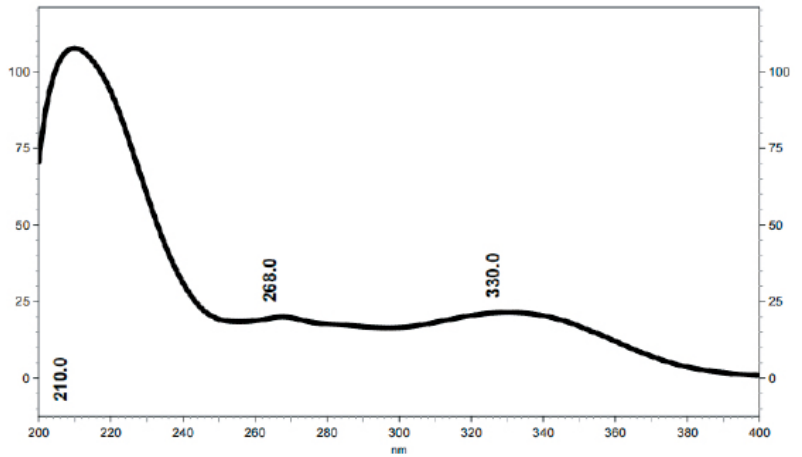

D

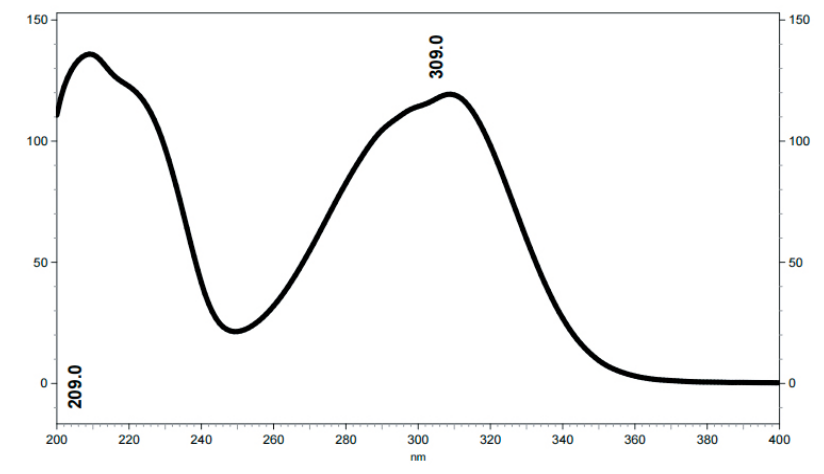

Figure 2. UV spectra of standard maker compound and maker compound in $\mathrm{Cl}$ and $\mathrm{CC}$ mixture.

(A), UV spectrum of standard astragalin; (B) UV spectrum of astragalin from Cl and CC mixture; (C), UV spectrum of standard $p$-coumaric acid m; (D), UV spectrum of $p$-coumaric acid from $\mathrm{Cl}$ and $\mathrm{CC}$ mixture. $\mathrm{Cl}$, Chrysanthemum indicum; $\mathrm{CC}$, Cymbopogon citratus. 
위해 HPLC 분석을 통해 각 지표 성분들의 함량을 구하였으며 그 결과 를 Table 3 에 나타내었다.

한편, 지표 성분의 기준은 함량이 많은 것을 선택하는 것이 바람직 하나, 동시 분석의 전제 조건에서 가장 중요한 기준 중의 한 가지는 동 시 분석하려는 소재들의 지표 성분이 HPLC 분석 과정에 각 피이크 가 겹치지 않아야 한다는 것이다. 선행연구에서 $\mathrm{LC} / \mathrm{MS}$ 를 이용하여 폴리페놀 또는 플라보노이드 성분 중 감국의 각 성분의 함량을 분석 한 결과, 가장 많은 함량을 차지한 것은 chlorogenic acid였으나, 레몬 그라스 역시 chlorogenic acid가 상당량(감국의 chlorogenic acid 함유 량의 $1 / 2$ ) 검출되어 각 추출물의 특이 성분으로 보기 어려워, 감국의 지표성분은 astragalin (AG)으로 선정하였다. 물론 레몬그라스에도 $\mathrm{AG}$ 가 함유되어 있으나 분석 결과 감국의 $\mathrm{AG}$ 함유량과 비교하여 극 히 소량(약 $1 / 33$ )인 점을 고려하여 결정하였다. 레몬그라스의 경우는 $p$-coumaric acid $(\mathrm{PA})$ 를 지표 성분으로 선정하였으며 감국에는 PA가 상대적으로 매우 미량 들어 있었다. Table 3에 나타낸 바와 같이, 감 국 $50 \%$ 에탄올추출물에서 $\mathrm{AG}$ 는 retention time $28.58 \mathrm{~min}$ 에 검출되 었으며 그 함량은 $0.24 \mu \mathrm{g} / \mathrm{mg}$ 이었다. 레몬그라스 $50 \%$ 에탄올추출물 에서 retention time $18.48 \mathrm{~min}$ 에 PA가 검출되었으며 그 함량은 1.55 $\mu \mathrm{g} / \mathrm{mg}$ 이었다. 감국추출물에서의 AG의 HPLC 프로파일(Figure $1 \mathrm{~A}$ ) 과 레몬그라스 추출물에서 PA의 HPLC 프로파일(Figure 1B), 지표 성 분의 구조(Figure 1C)를 Figure 1에 나타내었다(Kim, 2016).

\section{3. 동시분석 조건의 확립}

감국과 레몬그라스 각각의 지표성분인 $\mathrm{AG}$ 와 $\mathrm{PA}$ 를 $0.1 \%$ formic acid가 함유된 water와 $0.1 \%$ formic acid가 함유된 acetonitrile의 분 석 조건을 확립하여 동시 분석을 진행하였다. Figure 2 에서 볼 수 있 듯이, $\mathrm{AG}$ 는 $212,265,346 \mathrm{~nm}$ 에서 극대흡수파장을 나타냈으며, $p$-coumaric acid는 211, 226, $309 \mathrm{~nm}$ 에서 극대흡수파장을 나타내었 다. $\mathrm{DAD}$ 검출 파장은 $225,237,248,324$ 에서 검출하였다. 지표성분 들이 각각 $28.60 \mathrm{~min}, 18.73 \mathrm{~min}$ 에 모두 검출되는 것을 확인하였다.

\section{4. 특이성(speciticity)}

Figure 3 에 감국과 레몬그라스 추출물의 혼합물(Figure $3 \mathrm{~A}, 3 \mathrm{~B}$ ) 과 표준품(Fig $3 \mathrm{C}, 3 \mathrm{D})$ 의 크로마토그램을 비교한 것을 나타내었다. Figure $3 \mathrm{~A}$ 는 $\mathrm{AG}$ 표준품의 분석 파장인 $237 \mathrm{~nm}$ 에서 혼합물의 피크 이고 Figure $3 \mathrm{~B}$ 는 $\mathrm{PA}$ 표준품의 분석의 파장인 $248 \mathrm{~nm}$ 에서 혼합물의 피크이다. Figure $3 \mathrm{C}, 3 \mathrm{D}$ 는 각각 $\mathrm{AG}$ 및 $\mathrm{PA}$ 표준품의 피크이다. 혼합 물의 크로마토그램 중의 AG, PA 피크는 표준물질들의 retention time 과 일치하였으며, UV 흡광도를 비교하였을 때 서로 일치하므로 추 출물에 선정한 지표 성분인 $\mathrm{AG}$ 와 $\mathrm{PA}$ 가 존재한다는 것을 알 수 있다 (Figure 3).

\section{5. 직선성(Linearity), 검출한계(LOD) 및 정량한계(LOQ)}

Astragalin의 피크 면적에 대한 검량선은 $0.5-2.5 \mu \mathrm{g} / \mathrm{mL}$ 의 농도 범위에서 상관계수 $\left(\mathrm{R}^{2}\right)=0.9999$ 의 직선성을 나타내었으며, $\mathrm{PA}$ 는 $0.1-$ $1 \mu \mathrm{g} / \mathrm{mL}$ 의 농도에서 상관계수 $\left(\mathrm{R}^{2}\right)=0.9999$ 의 직선성을 나타내었 다. $\mathrm{AG}$ 의 검출 한계(LOD)는 $1.20 \mathrm{ng} / \mathrm{mL}$, 정량 한계는(LOQ)는 3.59 $\mathrm{ng} / \mathrm{mL}$ 이었으며, $\mathrm{PA}$ 의 검출 한계(LOD)는 $0.07 \mathrm{ng} / \mathrm{mL}$, 정량 한계는 (LOQ)는 $0.22 \mathrm{ng} / \mathrm{mL}$ 이다(Table 2).

\section{6. 회수율(recovery)}

추출물에 지표 성분 표준물질의 서로 다른 3 가지의 농도로 첨가 한 후 측정한 회수율을 분석한 결과를 Table 4에 나타내었다. 추출물 에 표준물질의 농도를 각각 $1,1.5,2 \mu \mathrm{g} / \mathrm{mL}$ 이 되도록 첨가하였을 때, 각 회수율(\%)은 $\mathrm{AG}$ 에서 $117.52,121.74,117.78 \%$ 였으며, 정확성 (RSD\%)은 각각의 농도에서 $0.46,0.07,0.16 \%$ 였다. $\mathrm{PA}$ 에서는 각 농 도에서 회수율(\%)은 102.20, 102.90, 102.17\%였으며, 정확성(RSD\%) 은 각각 $2.57,0.01,0.33 \%$ 로 나타났다.

\section{7. 정확성(accuracy) 및 정밀성(precision)}

회수율을 통해 일내(intra-day)와 일간(inter-day) 정확성을 측정 한 결과, 일내는 $\mathrm{AG}$ 에서 $108.48 \%, \mathrm{PA}$ 에서는 $110.58 \%$ 의 정확성을 나

Table 2. HPLC calibration data for astragalin, $p$-coumaric acid.

\begin{tabular}{lcccccc}
\hline Compound & $\begin{array}{c}\text { Linear range } \\
(\mu \mathrm{g} / \mathrm{mL})\end{array}$ & $\mathrm{t}^{\mathrm{R}}(\mathrm{min})$ & Equation & $\begin{array}{c}\text { Linearity } \\
\left(\mathrm{R}^{2}\right)\end{array}$ & $\begin{array}{c}\mathrm{LOD} \\
(\mathrm{ng} / \mathrm{mL})\end{array}$ & $\begin{array}{c}\mathrm{LOQ} \\
(\mathrm{ng} / \mathrm{mL})\end{array}$ \\
Astragalin & $0.5-50$ & 28.60 & $\begin{array}{c}\mathrm{Y}^{*}=1.43291 \mathrm{e}- \\
007 \mathrm{x}+0.000000\end{array}$ & 0.999924 & 1.20 & 3.59 \\
$p$-coumaric acid & $0.1-10$ & 18.73 & $\begin{array}{c}\mathrm{Y}=1.08174 \mathrm{e}- \\
007 x+0.000000\end{array}$ & 0.999961 & 0.07 & 0.22 \\
\hline
\end{tabular}

$\mathrm{Y}$, peak area; $\mathrm{x}$, standard concentration; $\mathrm{R}^{2}$, correlation coefficient. LOD, limit of detection; LOQ, limit of quantitation.

Table 3. Content analysis of the compounds in the extracts

\begin{tabular}{lccc}
\hline Compound & Retention time $(\mathrm{min})$ & Area & Contents $(\mu \mathrm{g} / \mathrm{mg})$ \\
Astragalin $(\mathrm{Cl})$ & 28.58 & 270829 & 0.24 \\
$p$-coumaric acid $(\mathrm{CC})$ & 18.48 & 1438368 & 1.55 \\
\hline
\end{tabular}

$\mathrm{Cl}$, Chrysanthemum indicum; CC, Cymbopogon citratus. 

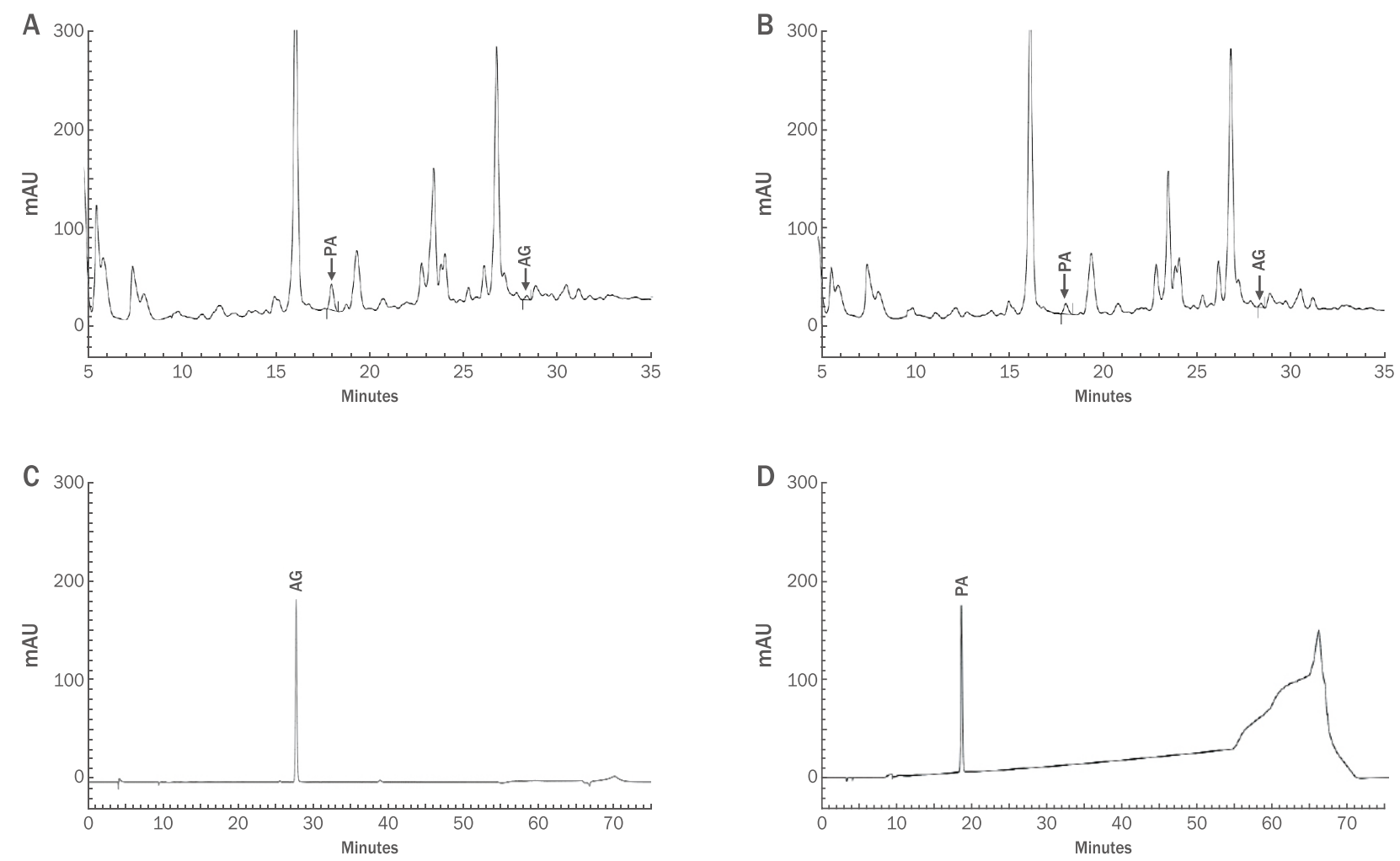

Figure 3. HPLC profile in simultaneous analysis of the $\mathrm{Cl}$ and $\mathrm{CC}$ mixture.

Panels (A) and (B) are chromatograms of mixed $\mathrm{Cl}$ and $\mathrm{CC}$ profiled at $237 \mathrm{~nm}$ (the maximum absorption wavelength for $\mathrm{AG}$ analysis) and $248 \mathrm{~nm}$ (the maximum absorption wavelength for PA), respectively. Panels (C) and (D) are the HPLC profiles of the AG and PA standards, respectively. Cl, Chrysanthemum indicum L.; CC, Cymbopogon citratus; AG, astragalin, PA, p-coumaric acid.

타내었고, 일간은 각각 $107.39,110.79 \%$ 의 정확성을 나타내었다. 회 수율은 식약처 가이드라인 기준치인 회수율 오차 $20 \%$ 이내를 만족 하였다. 직선성 범위 내에서의 일정한 3 가지 농도에서의 정밀성을 측 정한 일내(intra-day)와 일간(inter-day)의 시험결과, 일내는 AG에 서 $0.05 \%, \mathrm{PA}$ 에서는 $0.53 \%$ 정확성을 나타내었고, 일간은 각각 0.06 , $0.29 \%$ 의 정밀성을 나타내었다. 이는 가이드라인 기준치인 상대표준 편차 $5 \%$ 이하를 만족하였다(Table 5).

\section{Conclusion}

본 연구에서는 감국과 레몬그라스 에탄올 추출물을 활용한 천연 화장품 복합 조성물의 지표성분 표준화 및 다성분 동시분석법의 확 립을 위해 각각의 지표 성분을 $\mathrm{AG}$ 와 PA로선정하였고 HPLC-DAD 를 사용하여 직선성, 정확성, 정밀성 등의 분석을 수행하였다. 먼저, 감국과 레몬그라스의 $\mathrm{DPPH}$ 라디칼 소거 활성을 평가했을 때, 감국 의 $50 \%$ 에탄올추출물은 RC50이 $48.32 \pm 1.07 \mu \mathrm{g} / \mathrm{mL}$, 레몬그라스

Table 4. Recovery levels of astragalin and $p$-coumaric acid

\begin{tabular}{|c|c|c|c|c|}
\hline Compound & $\begin{array}{c}\text { Spiked } \\
\text { concentration }(\mu \mathrm{g} / \mathrm{mL})\end{array}$ & $\begin{array}{c}\text { Detected } \\
\text { concentration }(\mu \mathrm{g} / \mathrm{mL})\end{array}$ & Recovery (\%) & RSD (\%) \\
\hline \multirow{3}{*}{ Astragalin } & 1 & $0.24 \pm 0.00$ & 117.52 & 0.46 \\
\hline & 1.5 & $0.61 \pm 0.00$ & 121.74 & 0.07 \\
\hline & 2 & $1.18 \pm 0.00$ & 117.78 & 0.16 \\
\hline \multirow{3}{*}{$p$-coumaric acid } & 1 & $1.02 \pm 0.02$ & 102.20 & 2.57 \\
\hline & 1.5 & $1.54 \pm 0.00$ & 102.90 & 0.01 \\
\hline & 2 & $2.04 \pm 0.00$ & 102.17 & 0.33 \\
\hline
\end{tabular}

Recovery $(\%)=[($ amount found-original amount)/amount spiked $] \times 100 ; \mathrm{RSD}$, relative standard deviation. 
Table 5. Accuracy and precision data for quantitative determination of the two compounds

\begin{tabular}{|c|c|c|c|c|}
\hline \multirow{2}{*}{ Compound } & \multicolumn{2}{|c|}{ Intra-day ( $(n=3)$ ( ${ }^{*}$ first day) } & \multicolumn{2}{|c|}{ Inter-day (n=3) ("all day) } \\
\hline & Accuracy (\%) & Precision (RSD \%) & Accuracy (\%) & Precision (RSD \%) \\
\hline Astragalin & 108.48 & 0.05 & 107.39 & 0.06 \\
\hline$p$-coumaric acid & 110.58 & 0.53 & 110.79 & 0.29 \\
\hline
\end{tabular}

$\mathrm{RSD}$, relative standard deviation.

$50 \%$ 에탄올추출물은 $48.51 \pm 1.44 \mu \mathrm{g} / \mathrm{mL}$ 로 나타났으며, 두 추출물 의 $1: 1$ 조성물은 $37.96 \pm 0.31 \mu \mathrm{g} / \mathrm{mL}$ 로 나타났다. 각각의 추출물은 양성대조군으로 사용한 L-ascorbic acid $(52.10 \pm 0.49 \mu \mathrm{g} / \mathrm{mL})$ 보다 약 1.1 배 강했으며, 조성물은 1.4 배 더 강한 소거 활성을 나타내었 다. 감국에서 $\mathrm{AG}$ 의 함량은 $0.24 \mu \mathrm{g} / \mathrm{mg}$, 레몬그라스에서 $\mathrm{PA}$ 의 함량 은 $1.55 \mu \mathrm{g} / \mathrm{mg}$ 로 확인되었고 식약처 가이드라인에 적합한 직선성, 정확성, 정밀성 분석을 확립하였다. 이상의 결과로 설정된 분석법은 천연 화장품 소재의 제조 관리 및 품질관리를 위한 중요한 자료로 사 용 될 수 있을 것이라 사료되며, 향후, 감국과 레몬그라스의 단일 추 출물 및 조성물을 이용하여 우수한 천연화장품 소재로 개발하기 위 해서는 다른 생리활성을 추가로 분석할 필요가 있을 것이다.

\section{Acknowledgements}

본 연구는 농림축산식품부의 재원으로 농림수산식품 기획평가 원의 농림축산식품연구개발사업(과제번호: $317024054 \mathrm{SB} 020$ )의 지원에 의해 이루어진 결과로 감사드린다. 또한, 감국과 레몬그라 스 추출물을 공급해준 남원시 화장품산업지원센터에 감사드린다.

\section{Author's contribution}

JEK and JYL contributed equally to this work. JYL supervised the project, and JEK performed experimental design and analysis for HPLC analysis with the help of JYL. JYL and JEK wrote the manuscript together.

\section{Author details}

Ju Eun Kim (Graduate student), Department of Pharmacy, Woosuk University, 443, Samnye-ro, Samnyeeup, Wanju-gun, Jeollabuk-do 55338, Korea; Jae Yoou Leem (Professor), Department of Pharmacy, Woosuk University, 443, Samnye-ro, Samnye-eup, Wanju-gun, Jeollabuk-do 55338, Korea.

\section{References}

Ahn EM, Choi SA, Choi JY. HPLC analytical method validation of Aralia elata extract as a functional ingredients. Korean
Journal of Food Preservation, 24: 795-801, 2017.

Blois MS. Antioxidant determinations by the use of a stable free radical. Nature, 181: 1199-1200, 1958.

Bhattacharya AK, Kaul PN, Rajeswara Rao BR. Effect of prolonged storage on the quality of lemongrass (Cymbopogon flexuosus (nees ex Stuud.) Wats.) essential oil. Journal of Essential Oil-Bearing Plants, 1: 104-109, 1998.

Francisco V, Figueirinha A, Costa G, Liberal J, Lopes M. C, García-Rodríguez C, Batista MT. Chemical characterization and anti-inflammatory activity of luteolin glycosides isolated from lemongrass. Journal of Functional Foods, 10: 436-443, 2014.

Ham HN, Shrestha AB, Kim JE, Leem JY, Lee TB, Yoo BW, Kim MS, Kim KS, Cha JS, Lee YM, et al, Simultaneous analysis of the compounds of natural cosmetic resource containing Chrysanthemum zawadskii, Perilla frutescens, Rosa multiflora and their anti-oxidative activity. Korean Journal of Pharmacognosy, 49: 312-321, 2018.

Heo J. Donguibogam. Bubin Publisher, Seoul, pp577, 2017.

Hyun JM, Jo YJ, Kim YB, Park SM, Yoon KS, Lee NH. Antiinflammatory and anti-oxidative activities of flavonoids extracted from Dendranthema indicum flowers in Jeju Island. Journal of the Korean Applied Science and Technology, 36: 1259-1267, 2019.

IPAI RIsearch. Market trend of the cosmetics industry and k-beauty overseas. Industry policy analysis institute, Seoul, pp58-106, 2017.

Jo YS, Ju SM, Hwang KH, Kim KS, Kim MS, Jeon BH. Inhibitory effect of Cymbopogon citratus ethanol extracts on adipogenesis in 3T3-L1 preadipocytes. Journal of Physiology \& Pathology in Medicine, 33: 17-24, 2019.

Kim SJ, Park YM, Jung ST. Anticariogenic effects and inhibition of glucosyltransferase activity of Chrysanthemun indicum L. extracts. Journal of the Korean Society of Dietary Culture, 20: 341-345, 2005.

Kim SG, Hong IP, Woo SO, Jang HR, Han SM. Anew analysis 
of $p$-coumaric acid and trans-cinnamic acid in propolis by UPLC. Korean Journal of Pharmacognosy, 47: 186-191, 2016.

Kim YJ. Extracts of Chrysanthemum indicum Linne mediated regulation of MMP1 via JNK-AP1 pathway. Asian Journal of Beauty and Cosmetology, 14: 399-405, 2016.

Kim TJ. Easy to find Korean herbal medicine (Korean medicine). Hyeonamsa, Seoul, pp76-77, 1998.

KFDA. Raw material standardization paper for health functional food developers. Korea Food and Drug Administration, Seoul, pp6-13, 2008.

Lee SM. Quantitative analysis of Ginsenosides using relative response factors from Ginsenoside Rf. Asian Journal of Beauty and Cosmetology, 16: 211-219, 2018.

NIFDS. Drug validation guidelines. National Institute of Food and Drug Safety Evaluation, Seoul, pp1-19, 2015.
Park YM, Kim JI, Lee CH, Lim HJ, Seo EW. Effect of Dendranthema indicum extracts on cell and DNA damage induced by oxidative stress. Journal of Life Science, 21: 1698-1704, 2011.

So YK, Hwang JY, Kim HW, Jo HN, Lee TB. Skin hydration and skin barrier effects of Cymbopogon ciratus and Perilla frutescens extracts. Journal of the Society of Cosmetic Science Korea, 45: 225-235, 2019.

Woo JH, Shin SL, Lee HC. Antioxidant effect of $80 \%$ ethanol extracts obtained from three Dendranthema species. Korean Journal of Plant Resources, 23: 47-53, 2010.

Yong YS, Lee SM, Byun NY, Sun SU, Kim MJ, Jang SW, Jang WS, Lee SY, Yim SH. Antioxidant activities and validation of analytical method of marker compounds in strawberry fruits from various cultivars. Korean Journal of Food Science and Technology, 51: 517-523, 2019. 


\section{국문초록}

\section{감국과 레몬그라스 에탄올 추출물을 함유한 천연화장품 소재의 HPLC-DAD를 이용한}

\section{지표 성분 동시 분석 밸리데이션}

김주은, 임재윤

우석대학교 약학과, 전라북도 완주군, 한국

목적: 최근 화장품 산업의 핵심 원료에 대한 천연 추출물 및 천연 유래 성분에 대한 수요가 증가하고 있으나 그 제조 및 품질 관리 기준이 충분히 확립되어 있지 않다. 본 연구에서는 Chrysanthemum indicum (CI) 및 Cymbopogon cirtratus (OC)의 에탄올 추출물 을 사용하여 천연 화장품 조성물의 지표 성분을 표준화하고 분석방법을 확립하고자 하였다. 방법: LC/MS 분석을 통해 정량 분석 을 위한 지표 성분으로 astragalin과 $p$-coumaric acid를 선정하였다. HPLC-DAD를 사용하여 두 추출물의 혼합조성물에서 지표 성분을 동시에 분석했다. $\mathrm{HPLC}-\mathrm{DAD}$ 를 사용하여 직선성, 정확성 및 정밀성 분석을 수행했다. 결과: $\mathrm{CI}$ 의 지표 성분은 astragalin

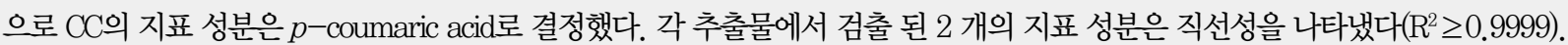
Astragalin과 $p$-coumaric acid의 검출 한계(LOD)는 각각 $1.20 \mathrm{ng} / \mathrm{mL}$ 와 $0.07 \mathrm{ng} / \mathrm{mL}$ 였으며, astragalin과 $p$-coumaric acid의 정 량 한계(LOQ)는 각각 $3.59 \mathrm{ng} / \mathrm{mL}$ 와 $0.22 \mathrm{ng} / \mathrm{mL}$ 였다. 각 지표 성분의 함량은 CI에서 $0.24 \mu \mathrm{gg} / \mathrm{mg}, \mathrm{CC}$ 에서 $1.55 \mu \mathrm{gg} / \mathrm{mg}$ 이었다. 결론: 두 허브에 대한 동시 분석법 확립 및 지표 성분의 선정을 통해 천연 화장품의 제조 및 품질관리를 위한 중요한 기초 자료로 활 용 될 수 있다.

핵심어: 밸리데이션, 동시분석, 항산화, 감국, 레몬그라스

본 연구는 농림축산식품부의 재원으로 농림수산식품 기획평가원의 농림축산식품연구개발사업(과제번호: $317024054 \mathrm{SB} 020$ )의 지원에 의해 이루어진 결과로 감사드린다. 또한, 감국과 레몬그라스 추출물을 공급해준 남원시 화장품산업지원센터에 감사드린다.

\section{참고문헌}

김선재, 박윤미, 정순택. 감국(Chrysanthemun indicum L.) 추출물의 항충치효과와 Glucosyltransferase 저해활성 탐색. 한국식생활문화학회지, 20: 341-345, 2005.

김세건, 홍인표, 우순옥, 장혜리, 한상미. UPLC를 이용한 프로폴리스 중 $p$-comaric acid와 Trans-cinnamic acid 분석

법. 생약학회지, 47: 186-191, 2016.

김영주. JNK-AP1 기전을 통한 국화꽃 추출물의 MMP1 발현 변화 조절. 아시안뷰티화장품학술지, $14: 399-405,2016$. 김태정. 쉽게 찾는 우리 약초 (한방편). 현암사, 서울, $\mathrm{pp} 76-77,1998$.

박영미, 김지인, 이창호, 임재환, 서을원. 국화추출물이 산화적 스트레스에 의해 유발되는 세포와 DNA 손상에 미치는 영

향. 생명과학회지, 21: 1698-1704, 2011.

산업정책분석원 RIsearch 센터. 화장품산업의 시장동향과 $\mathrm{K}$-뷰티 해외진출 방향 및 전략분석. 산업정책분석원, 서울, pp58-106, 2017.

식품의약품안전청. 건강기능식품개발자를 위한 원료 표준화 지침서. 식품의약품안전청, 서울, $\mathrm{pp6-13,2008.}$

식품의약품안전평가원. 의약품등 시험방법 밸리데이션 가이드라인. 식품의약품안정평가원, 서울, $\mathrm{pp} 1-23,2015$. 소양강, 황지영, 김현우, 조하늘, 이태범, 레몬그라스와 자소엽 추출물의 피부보습 및 피부장벽에 관한 연구. 대한화장품학

회지, 23: 47-53, 2010.

안은미, 최송암, 최지영. 두릅 추출물의 기능성 원료 표준화를 위한 HPLC분석법 검증. 한국식품저장유통학회지, 24 : 
795-801, 2017.

용예슬, 이송미, 변나영, 선상욱, 김민정, 장서우, 장원석, 이선이, 임순호. 딸기 품종별 추출물의 항산화활성 및 지표성분 밸리데이션. 한국식품과학회지, $51: 517-523,2019$.

이상명. Ginsenoside Rf에 대한 상대감응인자를 이용한 11종 진세노사이드의 함량분석. 아시안뷰티화장품학술지, 16 : 211-219, 2018.

우정향, 신소림, 이철희. 국화과 Dendranthema속 식물 3종 $80 \%$ 에탄올 추출물의 항산화 효과. 한국자원식물학회지, 23 : 47-53, 2010.

조용석, 주성민, 황금희, 김민숙, 김광상, 전병훈, 레몬그라스 에탄올 추출물의 3T1-L1 지방세포 분화 억제효과. 동의생 리병리학회지, 33: 17-24, 2019.

함하늘, 쉬레스타 아비나쉬 찬드라, 김주은, 이태범, 유병완, 김민숙, 김광상, 차준석, 이용문, 김종엽 et al. 산구절초, 자 소엽, 찔레를 함유한 천연 화장품소재의 다성분 동시분석과 항산화 활성. 생약학회지, 49: 312-321, 2018.

허준(동의문헌연구실 옮김). 법인문화사, 서울, p577, 2017.

현주미, 조연정, 김윤범, 박성민, 윤경섭, 이남호. 제주 자생 감국 꽃 추출물 유래 flavonoid 화합물의 항산화 및 항염활성. 한국응용과학기술학회지, 36: 1259-1267, 2019. 


\section{中文摘要}

\section{利用HPLC-DAD对含有菊花和柠檬草乙醇提取物的天然化妆品材料中的指示剂 成分进行同时分析}

金主恩，林載允

又石大学药学科，全罗北道完州郡，韩国

目的：近年来，化妆品行业对核心原料中天然提取物和天然衍生成分的需求有所增加，但其制造和质量控制 标准尚未得到充分确立。这项研究旨在使用菊花(Chrysanthemum indicum, $\mathrm{Cl}$ ) 以及柠檬草 (Cymbopogon cirtratus, CC)的乙醇提取物标准化天然化妆品中标志物的组成。然后验证该方法。方法: 在LC/MS中, 黄芪素和 对香豆酸被确定为定量分析的标志物。使用带有二极管阵列检测器的高效液相色谱法（HPLC-DAD），同时在两 种天然产物的混合物中分析了这两种标记物组分的性能（线性, 准确度和精密度）。结果：提取物中CI和CC的标 记化合物分别测定为黄芪素和对香豆酸。从CI和CC中检测到的标记化合物显示出显着的线性（0.9999）。黄芪 素和对香豆酸的检出限 (LOD) 分别为 $1.20 \mathrm{ng} / \mathrm{mL}$ 和 $0.07 \mathrm{ng} / \mathrm{mL}$ ，黄芪素和对香豆酸的定量限（LOQ）分别为 $3.59 \mathrm{ng} / \mathrm{mL}$ 和 $0.22 \mathrm{ng} / \mathrm{mL}$ 。标记物浓度在CI中为 $0.24 \mu \mathrm{g} / \mathrm{mL}$, 在CC中为 $1.55 \mu \mathrm{g} / \mathrm{mL}$ 。结论: 通过建立草药和 指示剂成分的同时分析方法，可以将其用作天然化妆品生产和质量控制的重要基础数据。

关键词: 验证，同时分析，抗氧化剂，菊花，柠檬草 
